\title{
MECHANISM OF TRANSFORMATION OF AGRICULTURAL ENTERPRISES IN TERMS OF INNOVATIVE DEVELOPMENT
}

\author{
Diana Shelenko, IVAn Balaniuk, Liudmyla Sas, Petro MatkovskyI, Iryna \\ KOZAK-BALANIUK
}

\begin{abstract}
The mechanism under study should be aimed at introducing innovative approaches to the modernization of technical 1 and technological cycles of production and economic processes, strengthening the competitive position of enterprises in the agrarian market and overcoming internal and external institutional barriers to enterprise development by suppressing irrational institutional influences on the functioning. The purpose of this study is to substantiate theoretical and methodological foundations and to develop applied approaches for implementing the mechanism of transformation of agricultural enterprises in a competitive environment. The scientific novelty of the obtained results lies in the substantiation of the mechanism of transformation of agricultural enterprises, which includes such components as: information and analytical tools (monitoring of the economic environment, verification and systematization of information data, establishment of essential laws and relationships, the formation of information bases of decision making, management, design-testing apparatus (designing a perspective plan for the transformation of agricultural enterprises, pilot testing of the target project of the proposed changes in the organizational and legal form of management, adjustment of the project of transformation of enterprises) and implementation-block (formation of innovative structures of agricultural enterprises, ensuring the sequence and consistency of implementation of target changes, minimization of conflict environment in the process of transformation in balancing the duties, process responsibilities and responsibilities in terms of the structural components of the new organizational and legal system). The social and economic effect of this mechanism is achieved through a synergistic effect obtained through the functional interaction of enterprises that are able, however, to work autonomously. The practical significance of the mechanism is manifested in the ability to generate comprehensive management support in the process of transformation of agricultural enterprises, taking into account the specifics of a particular organizational and legal form of management in a competitive environment of their operation.
\end{abstract}

Keywords: agricultural enterprises, transformation, integration, mechanism, monitoring. JEL Classification: F15, L25, O13.

\section{INTRODUCTION}

The market environment encourages agricultural enterprises to find ways to strengthen their position in the industry (market). Competition and the desire to function effectively necessitate 
constant innovative development of economic entities. Innovations are related to technological progress. The innovative potential of the enterprise is formed by a set of appropriate resources that create conditions for its movement in an innovative way. The ability of the enterprise to transform its activities in a diversified economy, including the organizational and legal form of management, is one of the directions of its innovative development in accordance with existing conditions.

The functioning of the domestic agrarian sector of the economy of Ukraine necessitates the implementation of continuous structural shifts, changes and upgrades in the system of production and economic activity of agricultural enterprises, which are able to ensure a high level of dynamic competitiveness, both in the internal and external agrarian markets given the impact of destabilization of financial threats. The modern subject-branch model of functioning of the agroindustrial complex, formed as a result of the long-term incompleteness of agrarian reform in the state, on the one hand ensured the redistribution of ownership rights to the means of production, the emergence of new organizational and legal forms of economic management in the agrarian market improving the efficiency of production and economic business processes of agricultural enterprises, the possibility of access of the population to the purchase of basic foodstuffs, the creation of prerequisites for strengthening the food security of the state, and on the other - laid the foundation for the production of threats to the irrational functioning of agricultural enterprises and the agrarian sector of the economy as a whole, namely: deepening of subject and sectoral imbalances in the development of the agricultural sector, lack of equal access of agricultural enterprises to the possibility of increasing their resource base, aggravation of agricultural enterprises, partial monopolization of certain segments of the agrarian market, strengthening of spatial and territorial disproportion of the development of rural areas, the formation of an irrational mechanism for the distribution of material goods among agricultural producers, limiting the parameters to support the processes of extended reproduction and sustainable development of agricultural enterprises.

\section{THEORETICAL BACKGROUND}

The transformational processes currently taking place in Ukraine's agriculture are an element of many scientific discussions. Today, the transformation processes occurring in agricultural enterprises are at an initial level. The transformation of organizational and legal forms of agricultural enterprises is considered by us as an institutional superstructure for improving the principles of their functioning, technical and technological apparatus of formation and implementation of management decisions and functional components of social and economic transformations in agricultural production.

Transformation processes in agriculture can be considered by the following criteria: economic content, orientation, main task, causes, scale, coverage of elements and character [1]. However, it will also be advisable to distinguish such criteria an institutional superstructure of the technical and technological apparatus, functional components of the implementation of social and economic transformations in the field of agricultural production.

The authors [2, p. 204] identify transformation through the prism of sustainable development, which is a general concept for balancing the needs of humanity and protecting the interests of future generations, including their need for a safe and healthy environment.

The transition of Ukraine to market relations also changed the system of attitude to transformation processes in agriculture, and including those related to the transformation of different organizational and legal forms of management [3, p. 204]. It can be argued that transformations carried out both in the regions and in Ukraine are insignificant because they did not contribute to the effective development of rural enterprises.

The central elements of the process of transformation of all economic instruments are that they operate at a decentralized level through their influence on market relations, not through the government [4, p. 658]. Agreeing with the above facts regarding the transformation of the agricultural sector, it is also worth noting the lack of clear benchmarks and the purpose of implementation. 
The transformation of agriculture is also seen as a gradual transition from a command and administrative to a market management system, and as a result will be a transition to a new economic system [5, p. 204].

In the definitions concerning the transformation of agricultural enterprises, it is important to note the increase in foreign direct investment and the openness of trade, which are important elements for the economic success of transformation processes [6, p. 253]. This theory is widely used in the scientific community and its influence on the formation of transformation processes needs further research.

The authors of [7, p. 35] also see the transformation of agricultural enterprises in the active growth and increase of the potential of renewable energy in them. We agree that rising electricity prices will encourage agricultural enterprises to develop renewable energy.

Among the most important processes of transformation of agricultural enterprises should be: be a social revival, new approaches to tax and financial policy [8, p. 43]. The studies explain that, when justifying the process of sustainable development of the agricultural sector, it is particularly important to provide the need for achievement strike a balance between social and financial costs in the economically viable economic activity of agricultural enterprises.

Considering the problems of transformation processes in agricultural enterprises the shortest way to bring the agriculture of Ukraine to the level of the most developed countries in agrarian relation is the creation and functioning of integrated associations with the participation of the financial, industrial capital and foreign investors [9, p. 166]. Agreeing with this statement, the problem is derived from the fact that a number of factors, in particular social, political, economic, organizational, and environmental factors, are affected by transformation processes, and the resolution of this problem should be the main focus of public policy.

Continuing to study the transformation processes in agricultural enterprises, it is necessary to consider the issues of accounting organization [10, p. 378]. That is, an effective mechanism for the transformation of agricultural enterprises should create opportunities to adapt their activities to changes in international standards.

Special attention is paid to the conclusions of a representative of the Bulgarian school, as he considers that the transformation processes should focus on establishing social relationships between entrepreneurs and entrepreneurship [11, p. 161]. In addition, an important point in researching the reasons that drive agricultural enterprises to transformation, as evidenced by the research conducted $[12$, p. 152], is a system of tools, levers and incentives used to shape and retain competitive advantage by influencing the enterprise's economic activity.

However, the question of the practical implementation of transformation processes in agricultural enterprises in a competitive environment remains open [13]. That is, transformation can act as evolution or change in the development of nature and society.

When researching the processes of the transformation, scientists often combine it with integration processes. In particular, scientists from Arkansas [14, p. 194], believe that the integration processes will mainly depend on better road quality, distance between markets. Integration processes are an objective tool that accumulates changes that are already evident in transformation processes, and a subjective tool can be created by the reform society to improve their effectiveness. Integration processes taking place in agricultural enterprises will help to improve food security and improve technical efficiency $[15$, p. 97]. In particular, their provisions relate only to what needs to be done to strengthen integration processes and competitive positions, but they do not specify how this should happen.

There is a considerable number of concepts of transformation and integration processes of agriculture in a competitive environment, the authors of which interpret the concepts of transformation processes differently without suggesting how they should occur in agricultural enterprises, which complicates the possibilities for its implementation.

Such prerequisites substantiate the feasibility of designing an effective mechanism for market transformation of agricultural enterprises, which will ensure the formation of resource capacity for the adequate prompt response of these enterprises to the emergence of threats in the economic environment and their functioning in the face of constant changes and information uncertainty. 
Development of the mechanism of transformation of agricultural enterprises of different organizational and legal forms of management in the conditions of a competitive environment should take into account:

- a priority model for the development of the agrarian sector of the economy and prospective directions of land reform in Ukraine;

- the imperfection of institutional support of agricultural production and economic activity;

- the innovative character of development and decision-making at macro, meso and micro levels of economic development;

- traditions of activity in the agrarian sector, as well as the formed experience of managers and employees of economic entities;

- resource limitations of material and financial resources of agricultural enterprises;

- information uncertainty in making management decisions by agricultural managers in market conditions;

- forecasts for the development of agricultural enterprises in the conditions of competition in meeting the needs of consumers.

\section{Research Objective, Methodology and Data}

The purpose of the article is to substantiate theoretical and methodological foundations and to develop applied approaches for implementing the mechanism of transformation of agricultural enterprises in a competitive environment.

Methodological principles of developing the mechanism of transformation of agricultural enterprises are: the necessity for innovative development of agricultural enterprises, in particular in the direction of transformation of organizational and legal forms of their management; consideration of transformation processes as an integral part of the market management system; priority of the human factor and managerial influence in the implementation of transformation processes; the need for timely and complete information support of this process; focus on social and economic efficiency of enterprises and the functioning of the industry.

Any mechanism consists of functional constituent components, elements, tools and blocks, a complex combination of which ensures the continuous operation of the target mechanism, the effective execution of the functions delegated to it and the strategic orientation to achieve a clearly set goal. In particular, the mechanism of transformation of organizational and legal forms of management of agricultural enterprises in a competitive environment provides for the feasibility of designing such a model of functioning of the agricultural enterprise, which will allow ensuring rational and balanced use of existing resource base, maximum parameters of efficiency of development of the main production and economic business processes of the enterprise, the high level of the rapid response of an agricultural enterprise to changes parameters of conditions of internal and external economic environment, as well as fulfillment of the strategic mission of the enterprise in the agrarian market.

Ensuring the functional capacity of the mechanism of transformation of agricultural enterprises of different organizational and legal forms of management in a competitive environment should include the following criteria based on the following principles:

- systematic (coherence of the functional elements of the target mechanism in the process of its operation, aimed at eliminating possible threats and internal contradictions in the implementation of its assigned functions);

- sustainability (the ability of the mechanism of transformation of agricultural enterprises to function in the conditions of the impact of destabilization of negative factors);

- balance (the existence of a rational organizational structure of the target mechanism, which provides for the optimal distribution of powers, duties and responsibilities between its constituent components);

- consistency (conformity of the mechanism of transformation of organizational and legal forms of agricultural enterprises to modern challenges, requests and needs of their business environment); 
- adaptability (ability of the target mechanism to respond promptly to perspective changes in the parameters of functioning of agricultural enterprises);

- autonomy (the ability of individual structural components of the mechanism to continuously perform the functions assigned to them, regardless of the performance of other components of this mechanism);

- forecasting (the ability of the target mechanism to diagnose the input information and produce prognostic scenarios for the development of transformation processes of agricultural enterprises).

In the course of research, the methods of generalization, systematization, system, sociological, analysis, tabular, graphic are used.

The information base of the study was the work of agrarian economists, data from the State Statistics Service of Ukraine, the results of a questionnaire.

\section{RESUlTS AND DisCUSSION}

The functioning of agricultural enterprises of various organizational and legal forms in 2007-2018 and trends in their transformation are given in table. 1.

\begin{tabular}{|c|c|c|c|c|c|c|c|c|}
\hline \multirow{2}{*}{$\begin{array}{c}\text { Organizational and } \\
\text { legal forms of } \\
\text { management }\end{array}$} & \multirow{2}{*}{$\begin{array}{c}\text { Unit of } \\
\text { measure } \\
\text { ment }\end{array}$} & \multicolumn{5}{|c|}{ Year } & \multicolumn{2}{|c|}{$\begin{array}{c}2018 \text { to, } \% \text {, percentage } \\
\text { points }\end{array}$} \\
\hline & & 2007 & 2012 & 2015 & 2017 & 2018 & $2007 \mathrm{p}$. & $2012 \mathrm{p}$. \\
\hline \multirow{2}{*}{ Business associations } & unit & 7428 & 8235 & 7721 & 6967 & 7148 & 96,2 & 86,8 \\
\hline & $\%$ & 12,72 & 16,66 & 17,02 & 15,29 & 16,01 & $-3,29$ p.p. & $-0,65$ p.p. \\
\hline \multirow{2}{*}{ Private enterprises } & unit & 4229 & 4220 & 3627 & 3215 & 3134 & 74,1 & 74,3 \\
\hline & $\%$ & 7,24 & 8,54 & 7,99 & 7,06 & 7,02 & $-0,22$ p.p. & $-1,52$ p.p. \\
\hline \multirow{2}{*}{ Farms } & unit & 43475 & 34035 & 32303 & 34137 & 33164 & 76,3 & 97,4 \\
\hline & $\%$ & 74,46 & 68,88 & 71,19 & 74,93 & 74,28 & $-0,18$ p.p. & 5,4 p.p. \\
\hline \multirow{2}{*}{$\begin{array}{l}\text { Agricultural } \\
\text { production } \\
\text { cooperatives }\end{array}$} & unit & 1262 & 848 & 596 & 448 & 429 & 34,0 & 50,6 \\
\hline & $\%$ & 2,16 & 1,72 & 1,31 & 0,98 & 0,96 & $-1,2$ p.p. & $-0,76$ p.p. \\
\hline \multirow{2}{*}{ Others enterprises } & unit & 1633 & 1781 & 891 & 592 & 589 & 36,1 & 33,1 \\
\hline & $\%$ & 2,8 & 3,6 & 1,96 & 1,3 & 1,32 & $-1,48$ p.p. & $-2,28$ p.p. \\
\hline \multirow{2}{*}{ State enterprises } & unit & 360 & 296 & 241 & 199 & 183 & 50,8 & 61,8 \\
\hline & $\%$ & 0,62 & 0,6 & 0,53 & 0,44 & 0,41 & $-0,21$ p.p. & $-0,19$ p.p. \\
\hline \multirow{2}{*}{ Together } & unit & 58387 & 49415 & 45379 & 45558 & 44647 & 76,5 & 90,3 \\
\hline & $\%$ & 100 & 100 & 100 & 100 & 100 & 100 & 100 \\
\hline
\end{tabular}

Tab. 1. Number of all organizational and legal forms of agricultural enterprises of Ukraine for 2007-2018. Source: [16, p. 138].

In 2018, compared to 2007, there was a quantitative decrease in all registered forms of agricultural enterprises, which indicates their merger and consolidation, reorganization and liquidation. One of the possible variants of this decline is also the processes of transformation, in particular the registration of new companies, as well as those that were inseparable structural units of processing and other enterprises. In general, reductions also occurred in business associations by 3,8 \%, private enterprises by $25,9 \%$, farms by $23,7 \%$, agricultural cooperatives by $66,0 \%$, other enterprises by $63,9 \%$ and stateowned enterprises - by $49,2 \%$.

Substantiation of the mechanism of transformation of agricultural enterprises is important in view of the deepening of irrational tendencies of functioning of the agrarian sector of the Ukrainian economy, which implies an increase in the excessive concentration of production and economic capacities of certain entities of agro-industrial complex and the strengthening of competitive positions of the so-called agroholdings markets. This situation is dangerous not only for the economic aspects of management (exacerbation of unfair competition, complication of access to the market of small 
agricultural producers, deepening of industrial and sectoral imbalances in the agrarian market), but also social (deepening of unfair distribution of material goods strengthening in the balance of social balances in society imbalance of spatial regional development of rural territories, reducing the level of social responsibility of economic entities to the rural population) and environmental (reproduction obstruction productive capacity of ecosystems in rural areas, complicated solution of problems of rational use of nature, total irrational intensification of production and economic processes of agricultural enterprises).

It should be noted that the strategic criterion for optimizing the design of the functional components of the mechanism of transformation of organizational and legal forms of agricultural enterprises must be the priority of increasing the parameters of the efficiency of the development of basic business processes. In addition, achieving this goal is complicated by the systemic imperfection and imbalance of the institutional environment of agribusiness entities. In this regard, the targeted mechanism of transformation, on the one hand, should be focused on the introduction of innovative modernization of technological cycles of production and economic processes and strengthening the competitive position of agricultural enterprises in the agrarian market, and on the other - overcoming existing internal and external institutional barriers of development of these enterprises by displacing irrational institutional influences on the functioning of the latter. This will provide an opportunity to create an adequate subjective structural model of functioning of domestic agriculture based on the formation of a priority institutional agrarian matrix, which will meet the requirements and needs of the market, and will also allow taking into account the interests of all participants of the food value chain in the environment of agricultural production: suppliers, producers, intermediaries and consumers of agricultural products.

Improvement of organizational and legal forms of management of agricultural enterprises in the process of transformation should provide the formation of opportunities for comprehensive development of personnel staff of these enterprises, improvement of its professional competences, continuous intellectual perfection, building of high moral and ethical standards of corporate culture organization, improvement of the moral and psychological standards. Strengthening material and intangible forms of work motivation, as well as increasing the level of social individual employee's responsibility for the end result of his activities in the process of production and economic activity.

The conceptual scheme of the transformation of agricultural enterprises of different organizational and legal forms of management is presented in Fig. 1.

The applied significance of the transformation of agricultural enterprises is that this process will allow a particular entity to choose the most acceptable in modern realities of organizational and legal form of management given the availability and adequacy of resources (material and technical, personnel, information, etc.).

Transformation of agricultural enterprises of different organizational and legal forms of economic activity suggests expediency of realization of structural changes in activity of these enterprises, and also requires preconditions on flexible characteristics which could provide possibility of implementation of projected changes in the functioning of transformation mechanism of agricultural enterprises. Therefore, ensuring the efficiency of transformation processes should occur in the context of such complex implementation of preparatory procedures as:

- monitoring of the economic environment of the agricultural enterprise (involves a complex organization of collecting internal and external information data, their processing, systematization and storage in order to minimize the risks of uncertainty of the information environment regarding management decisions in the process of transforming the organizational and legal form of enterprise management in a competitive environment);

- diagnostics of strategic business processes of an agricultural enterprise (aimed at identifying structural gaps and weaknesses of the organization of production and economic activity of the enterprise, identifying the mismatch of its sectoral structure to the available resource provision, definition of restrictions that constrain the increase of production and economic capacity of 
organizational and legal nature search of space capacity of increasing the parameters of efficiency of functioning of agricultural enterprises);

- modeling of priority directions of agricultural enterprise development (involves implementation of project procedures for forecasting probable optimistic and pessimistic scenarios of enterprise development taking into account potential parameters of its production and economic capacities, promising consumer expectations in the agrarian market and obtained competitive advantages, due to potential, implemented changes of organizational and legal nature in the activity of agricultural enterprise).

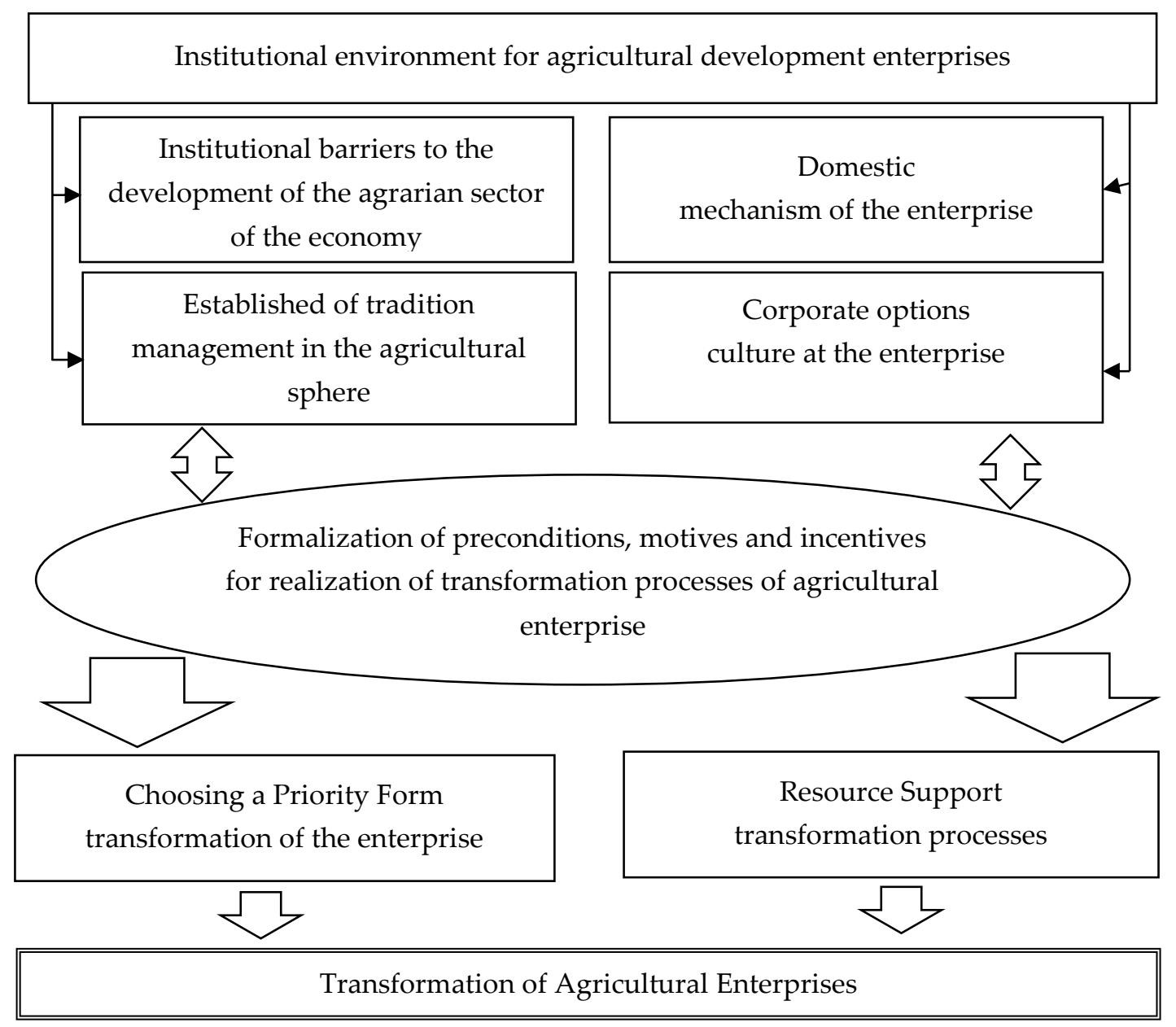

Fig. 1. The scheme of transformation of agricultural enterprises. Source: developed by the authors.

The implementation of the mechanism of transformation of organizational and legal forms of agricultural enterprises implies the implementation of systemic changes, the realization of which may hinder both individual representatives of management and specific employees of the enterprise. This is due to a number of factors, including the low level of adaptation of personnel to new parameters of functioning of the agricultural enterprise, in particular the inert nature of thinking of employees, fears of losing some of their powers and expanding the area of responsibility of managers, unwillingness to learn and improve their professional skills and the rate of pay margin in the form of wages, the probability occurrence of a potential conflict of interest between workers of the agricultural enterprise, the risk of destruction of established industrial and economic linkages and business relationships between contractors.

Logically, such fears and possible opposition to potential changes in the process of transformation of agricultural enterprises have subjective rather than objective character. Therefore, the implementation of the applied aspects of the target mechanism should take into account the social and psychological aspects of the transformation of organizational and legal forms of agricultural 
enterprises, which explains the benefits of the transition to new principles of management, minimization of staff turnover in the process of changing the organizational and legal form of agricultural enterprise, to strategic focus on preservation enterprise in the context of minimizing the dismissals of the most qualified employees, the possibility of career advancement and improvement of personnel motivation of staff in the process of transformation of agricultural enterprises, eliminate conflicts and complex moral and psychological climate in the team change the results of the legal form of management.

The biggest systemic changes in the process of transformation of agricultural enterprises occur in the organizational structure of the latter. In this aspect, it is important not only to ensure a balance of managerial influences in the process of implementation of transformational changes, but also to design a rational organizational structure of the agricultural enterprise, optimal distribution of functional responsibilities between the structural units of the enterprise, guaranteeing the parity of control powers of management personnel. Perspective organizational structure of an agricultural enterprise should be coordinated with its priority production directions, which will allow to ensure a harmonious combination of organizational management and production-economic processes, to guarantee the maximum effective use of the existing resource base of the enterprise, to increase the efficiency of strategic business processes development, to improve the economic activity of the enterprise, to minimize management and transaction costs in the process of implementing the mechanism of transformation of agricultural enterprises of different organizational and legal forms of management.

The mechanism of transformation of business societies, including powerful agroholding structures, should first and foremost aim at enhancing social component and responsibility in the process of managing and utilizing the capacity of rural ecosystems. Thus, the improvement of the organizational and legal form of economic activity should provide for the creation in the structure of companies of socially-focused trust funds for the support of employees of agricultural enterprises, improvement of their working and living conditions, increasing quality of life of the rural population, development of objects of the social and economic infrastructure of rural territories. Adherence to this approach will not only stimulate the level of social justice of distribution of material goods among the participants of agrarian production, but will also cause a structural impulse to improve the motivation of the employees of the companies, which in the aggregate will increase the efficiency of work of the personnel staff of the enterprises. In this context, it is important to ensure equal access for employees of the enterprise to investment opportunities in the production and economic activities of the agricultural enterprise through the acquisition of a share in the authorized capital, which, on the one hand, will allow diversifying sources of filling the financial capacities of companies, and on the other - to guarantee participation of employee of the company in the distribution of future profits. The strategic task of the mechanism of transformation of powerful agroholding structures is the formation of a rational model of concentration of production and resource capacities (agricultural lands, financial resources, agricultural machinery, human capital). In this regard, it is advisable to implement tools to stimulate the legal registration of structural units of agricultural holdings at the actual place of business. This minimizes the risk of excessive irrational concentration of agricultural production capacities and reduced management of strategic business processes, and creates the preconditions for filling the budgets of rural councils through the implementation of tax payments.

In the process of transformation of private agricultural enterprises, an important aspect of the activity is the strategic formation of opportunities to increase their production capacity and create the preconditions for attracting external borrowing capital, aimed at improving the material base and increasing the level of technical and technological support. Therefore, it is advisable both to implement the mechanisms of transformation of some agricultural enterprises into joint stock companies, and to preserve the traditional way of management and organization of production and economic processes, the target of which should be the production of quality organic agricultural products, guaranteeing a rich competitive environment in the agricultural market preservation of principles of rational nature management in the countryside. The transformation of the organizational and legal form of management of private agricultural enterprises should correspond to the formation of their rational 
production and branch model. This situation from one point of view makes it advisable to focus on expanding the scale of enterprise management, developing new niches in the agrarian market, intensifying the process of implementation of innovative projects in agroindustrial complex, diversifying the manufacturing of products at the agricultural enterprise, and from another optimizing production and industry structure of management harmonization of strategic goals with enterprise resource capacities, balancing of crop and livestock industries, stimulation of nonagricultural species of business activities. Ensuring adherence to such an approach will lead to the prerequisites for the formation of a number of competitive advantages for private agricultural enterprises, such as construction of closed cycle waste-free production, rational use of natural ecosystems capacity, support for fertility restoration of soil cover of agricultural land, partial avoidance of seasonal to the agricultural enterprise only agrarian production, overcoming imbalances in financial flows agricultural during the calendar year.

In the process of forming strategic orientations of the mechanism of transformation of production cooperatives it is advisable to take into account the specific characteristics inherent in this organizational and legal form of economy, such as integration approaches to the organization of agricultural production, the practice of collegial decision making, joint management of the production capacities of cooperatives administration features of productive and economic activity of the cooperative, parity distribution of powers, duties, responsibilities and volumes of the received profits between the statutory members of the cooperative association. Transformation of an agricultural production cooperative should involve building vertically-integrated relationships between valueadded entities, business relationships that must be clearly regulated and harmonized, which, on the one hand, will form the prerequisites for optimal efficiency of vertically-integrated business processes. and, on the other, minimizes the risk of conflict and confrontation between the members of the cooperative association. Priority is given to strengthening the function of servicing cooperative structures in the context of limited logistical support for agricultural enterprises and households, which requires the design of a target format for the organization of cooperative relationships with other participants in the agricultural sector based on the expansion of the traditional list of major types of economic growth services in the profit structure of the cooperative association.

The formation of a balanced model of the agrarian sector of the Ukrainian economy provides for the feasibility of establishing and supporting the development of farms as a priority organizational and legal form of farming in rural areas. The defining role of farming is not only to provide the population with quality organic products, but also to increase the level of competitive environment in the agrarian market, to intensify the processes of agrarian deconcentration, to increase employment among the rural population and to form a strong middle class in rural areas. At the same time, imperfect reforms and institutional processes could not adequately influence the establishment and approval of farms that meet the requirements and needs of the time. Therefore, the implementation of the mechanism of transformation of farms should be aimed at their structural restructuring, increasing production and economic capacity and strengthening competitive positions in the agrarian market. In order to do this, it is necessary to form incentives for consolidation of farm resource capacities, to create regional farm clusters of agricultural production, to implement tools for lobbying the interests of farms in the agrarian market, to improve the management, financial and accounting and statistical support of agricultural production. According to M. Shulsky, significant financial resources are needed to solve this problem, which are insufficient in farms [17, p. 296]. Priority is given to institutional support for the establishment of farms on a family-type basis, which, on the one hand, will overcome the negative social and economic consequences of structural unemployment in rural areas, and on the other hand, will ensure the adoption of approaches to the rational use of natural ecosystems in rural areas and responsible attitude of the farmer-owner for his final management results.

The functioning of the mechanism of transformation of organizational and legal forms of management in the segment of state agricultural enterprises should be aimed at overcoming irrational approaches to the organization of management of these enterprises. It should be noted that state agricultural enterprises are characterized not only by low economic performance, but also by the loss of 
agricultural production, irrational approaches to management, corruption and abuse in the use of state property owned by these enterprises, including in land use. Therefore, the transformation of state agricultural enterprises must be aimed at reducing the share of the public sector in the process of managing and organizing production and business economic processes on the basis of privatization procedures with the possibility of selling the assets of enterprises at the maximum possible price, partial transfer of agricultural land of state enterprises in the possession of newly created united territorial communities, transformation of enterprises into business associations and private enterprises. Adherence to this approach will create preconditions for overcoming structural abuses in the sphere of state property in the agro-industrial complex, and will also improve the efficiency of the latter in the economic process.

Substantiation of the mechanism of transformation of agricultural enterprises of different organizational and legal forms of management provides for the expediency of developing its structural components, such as informational and analytical tools, design-testing apparatus and implementationblock, which, on the one hand, are capable of working independently and, on the other their synergistic combination of functional interaction is capable of generating complex managerial support in the process of effective transformation of agricultural enterprises in a competitive environment, considering the specific organizational and legal form of business management.

The informationally analytical toolkit of the mechanism of transformation of organizational and legal forms of agricultural enterprises should reduce the level of uncertainty regarding the decisionmaking in the process of transformation. For this purpose, it is necessary to organize the collection, processing and systematization of input information, their verification, validation and diagnostics for further formulation of objective conclusions and proposals regarding perspective directions of transformation and development of agricultural enterprise in the competitive environment of the agrarian sector of the Ukrainian economy. It is advisable to set up monitoring structures to observe changes in the parameters of the conditions of the internal and external environment of the agricultural enterprise, installation the deviation of the absolute values of the main indicators of production and economic activity from their maximum permissible norms, identify potential threats that may disrupt the effective functioning of the enterprise in the conditions of liberalization of the agrarian market. The objective final results of the functioning of the information and analytical toolkit of the mechanism of transformation of agricultural enterprises is a fundamental basis for guaranteeing an adequate level of efficiency of transformation processes of organizational and legal forms of management.

The functioning of the design-testing apparatus of the transformation mechanism is aimed at developing a priority direction for adjusting and changing the existing organizational and legal form of management of an agricultural enterprise. Within this structural component of the target mechanism, it is advisable to test prospective options for the development of an agricultural enterprise, to coordinate its resource capabilities with strategic goals and objectives, to identify potential economic risks and losses of an agricultural enterprise in the transformation process. At this stage, it is important to ensure the flexibility of the design procedures, which will provide opportunities for prompt adjustment of the targeted transformation project, taking into account the maximum number of rational comments and proposals, minimizing the budget costs of the agricultural enterprise in the process of transformation of its organizational and legal form of management. The formalization of the design-testing apparatus implies the availability of a high level of intellectual and human resources of the agricultural enterprise, since the project work requires the implementation of a set of experimental procedures in the conditions that are as close as possible to the real ones. Therefore, an alternative for small and mediumsized agricultural enterprises may be the use of outsourcing technology in the process of developing a targeted transformation project that will provide adequate support for managerial decision-making.

The decisive structural component of the mechanism of transformation of organizational and legal forms of agricultural enterprises is the implementation and production unit, whose operation is aimed at introducing priority changes in the production and economic process. Within this component, it is important to form new organizational structures, minimize the risks of resistance of agricultural workers to implemented changes, ensure a clear sequence and consistency of actions in the process of 
implementation of the developed enterprise transformation project, overcome potential conflicts of interest, maintain established business relationships and contacts of rural businesses counterparties, reduce the transaction costs of the enterprise in the transformation process, minimize the risks of disruption by approved plan of the transformation of the organizational and legal form of agricultural enterprise.

The priority goals, objectives and instruments of implementation of the mechanism of transformation of agricultural enterprises should be differentiated depending on the specifics of a certain organizational and legal form of management. This is caused not only by the effect of the scale of management of the agricultural enterprise but also by the way of organization of production and economic processes, applied principles of formation and distribution of capital, strategic priorities of the agricultural enterprise in the agrarian market, the level of its technical and technological equipment and unused reserves of personnel potential of the enterprise. Implementation of the proposed mechanism of transformation of agricultural enterprises of different organizational and legal forms in a competitive environment requires adequate budget support, the sources of which may be both internal and external funding reserves. It is important in this process that the criteria of optimality regarding the economic feasibility of the potential costs are, taken into account, the scale of the potential economic benefit and the useful effect resulting from the implementation of the design transformation procedures.

\section{CONCLUSIONS}

Thus, we believe that the mechanism of transformation of organizational and legal forms of agricultural enterprises in a competitive environment is an element of its innovative development. Unlike the existing ones, this mechanism should be positioned through a prism:

- institutional superstructure for improving the fundamental principles of functioning of agricultural enterprises;

- technical and technological apparatus of formation and implementation of managerial decisions in the process of management;

- functional components of implementation of social and economic transformations in the field of agricultural production. The complex implementation of the proposed mechanism will create the preconditions for strengthening the competitiveness of agricultural enterprises, improving the efficiency of their business processes and establishing the principles of rational environmental management in the field of agricultural production.

It should be mentioned that such sectoral subjective distribution of agricultural production has a negative impact on the functioning of the agroindustrial complex and the formation of its competitive position in both domestic and foreign markets, since it provides for the inability to guarantee the production of quality and safe products due to limited control procedures in households, institutional restrictions on the acceptance of agricultural raw materials produced in households by processing enterprises, the problem of the shadow market of agricultural products and so on.

The task of agricultural enterprises in the implementation of this mechanism is also to increase the level of marketability of existing farms, institutionalization of production and economic activities of the latter, the development of cooperative and integration processes between households.

The subjects of the proposed mechanism are agricultural enterprises, which, given the significant role in the agricultural market, especially in the supply of livestock products, are forced to look for effective mechanisms and incentives for the transformation of households into farms and small agricultural enterprises. 


\section{REFERENCES}

[1] Sosnytska J.S. Transformation in agriculture as an object of study of social geographical sciences. Scientific Review, 3 (13) (2015). Available at: https://naukajournal.org/index.php/naukajournal/article/ view/441/619 (in Ukrainian)

[2] Pylypiv N.I., Maksymiv Yu.V., Piatnychuk I.D. Conceptual approach to construction of accounting and information provision of social responsibility for business enterprises through the prism of the business partnership system. Financial and credit activity: problems of theory and practice, 4 (27) (2018), 201-211. doi: 10.18371/fcaptp.v4i27.154374 (in Ukrainian)

[3] Balaniuk I., Kozak I., Shelenko D., Balaniuk S., Kozak-Balaniuk I. Forecasting of Gross Agricultural Output of Agrarian Enterprises of Ukraine: Case Study with STELLA Software. Economic Studies (Ikonomicheski Izsledvania), 28 (5) (2019), 148-163.

[4] Yakubiv V., Panukhnyk O., Shults S., Maksymiv Y., Hryhoruk I., Popadynets N., Bilyk R., Fedotova Y., Bilyk I. Application of Economic and Legal Instruments at the Stage of Transition to Bioeconomy. Advances in Intelligent Systems and Computing, 965 (2019), 656-666. doi: 10.1007/978-3-030-20454-9_64

[5] Smoleniuk R.P. The transformation of agrarian sector of economy on principles of sustainable development. Innovative Economy, 6 (2014), 14-20. Available at: http://nbuv.gov.ua/UJRN/inek_2014_6_3 (in Ukrainian)

[6] Tariq G., Sun H., Haris M., Kong Y., Nadeem A. Trade liberalization, FDI inflows economic growth and environmental sustanaibility in Pakistan and India. Journal of Agriculture and Environment for International Development (JAEID), 112 (2) (2018), 253-269. doi: 10.12895/jaeid.20182.722

[7] Yakubiv V., Boryshkevych I. Strategic analysis of the development of renewable energetics in the world and in Ukraine. Journal of Vasyl Stefanyk Precarpathian National University, 5 (3-4) (2018), 33-43. doi: 10.15330/jpnu.5.3-4.33-43

[8] Sabluk P.T. Agrarian policy and transformational change is in agriculture of Ukraine of period of becoming of market. Transformation of rural agriculture: anniversary collection of scientific articles (2010), 41-47. (in Ukrainian)

[9] Cherevko G.V. Development of agroindustrial complex is in context of transformation of national economy. Transformation of rural agriculture: anniversary collection of scientific articles (2010), 157-168. (in Ukrainian)

[10] Yakubiv V.M., Shelenko D.I., Sas L.S. Fixed assets accounting: National and international aspects, Actual Problems of Economics, 11 (173) (2015), 375-379. (in Ukrainian)

[11] Angelova M. Performance of Social Entrepreneurs and Social Entrepreneurship in Bulgaria. Economic Studies (Ikonomicheski Izsledvania), 28 (6) (2019), 160-191.

[12] Nykolyuk O.M. Cost Management as a Mechanism for Ensuring the Competitiveness of Agricultural Enterprises. Biznesinform, 4 (2016), 150-156. (in Ukrainian)

[13] Nakonechna K.V. Problems and prospects of transformation processes of the agricultural sphere at the regional level. Efektyvna ekonomika, 2 (2013). Available at: http://www.economy.nayka.com.ua/?op $=1 \& \mathrm{z}=1810$ (in Ukrainian)

[14] Tsiboe F., Dixon B.L., Wailes E.J. Spatial dynamics and determinants of Liberian rice market integration. African Journal of Agricultural and Resource Economics, 11 (3) (2016), 183-196. doi: 10.22004/ag.econ.245938

[15] Asekenye C., Bravo-Ureta B.E., Deom M., Kidula N., Kalule Okello D., Okoko N., Puppala N. Productivity gaps among groundnut farmers in Kenya and Uganda: A stochastic production frontier analysis. African Journal of Agricultural and Resource Economics, 11 (2) (2016), 85-100. doi: 10.22004/ag.econ.241851

[16] Shelenko D.I. Organizational and legal forms of agricultural enterprises in the economic dimension. Vasyl Stefanyk Precarpathian National University, Ivano-Frankivsk, 2019. (in Ukrainian)

[17] Shulskyi M.H. Farming: Problems of Installation and Development. Stepan Gzhytskyi National University of Veterinary Medicine and Biotechnologies, Lviv, 2004. (in Ukrainian) 
Address: Diana Shelenko, Ivan Balaniuk, Liudmyla Sas, Petro Matkovskyi, Vasyl Stefanyk Precarpathian National University, 57 Shevchenko St., Ivano-Frankivsk, 76018 Ukraine;

Iryna Kozak-Balaniuk, John Paul II Catholic University of Lublin, 14 Aleje Racławickie, Lublin, 20950 Poland.

E-mail: diantsya@ukr.net, ifbalaniuk@gmail.com, sas_lyudmyla@ukr.net, petromatkovskyy@gmail.com, irenakozak@gmail.com

Received: May 5, 2020; revised: July 10, 2020.

Шеленко Діана, Баланюк Іван, Сас Людмила, Матковський Петро, Козак-Баланюк Ірина. Механізм трансформації сільськогосподарських підприємств в умовах їхнього інноваційного розвитку. Журнал Прикарпатського університету імені Василя Стефаника, 7 (3) (2020), 115-127.

Механізм трансформації сільськогосподарських підприємств спрямовується на впровадження інноваційних підходів до модернізації техніко-технологічних циклів виробничо-господарських процесів, зміцнення конкурентних позицій підприємств на аграрному ринку та на подолання внутрішніх і зовнішніх інституційних бар'єрів розвитку підприємств шляхом витіснення ірраціональних інституційних впливів щодо функціонування останніх. Метою даного дослідження є обгрунтування теоретико-методологічних засад і розробка прикладних підходів для реалізації механізму трансформації сільськогосподарських підприємств в умовах конкурентного середовища. Наукова новизна одержаних результатів полягає в обгрунтуванні механізму трансформації сільськогосподарських підприемств, який включає такі складові, як: інформаційно-анадітичний інструментарій (моніторинг економічного середовища, верифікація та систематизація інформаційних даних, встановлення істотних закономірностей і взаємозв'язків, формування інформаційного базису прийняття управлінських рішень), проєктно-апробаційний апарат (проєктування перспективного плану трансформації сільськогосподарських підприємств, пілотне тестування цільового проєкту пропонованих змін організаційно-правової форми господарювання, корегування проєкту трансформації підприємств) та імплементаційно-постановочний блок (формування інноваційних структур сільськогосподарських підприемств, забезпечення послідовності та узгодженості впровадження цільових змін, мінімізація конфліктного середовища в процесі трансформації, збалансування повноважень, обов'язків і відповідальності у розрізі структурних складових нової організаційно-правової системи). Соціально-економічний ефект зазначеного механізму досягається завдяки синергічному ефекту, отриманому завдяки функціональній взаємодії підприємств, спроможних, однак, працювати автономно. Практичне значення механізму проявдяється у здатності генерувати комплексну управлінську підтримку у процесі трансформації сільськогосподарських підприємств з урахуванням специфіки конкретної організаційно-правової форми господарювання в умовах конкурентного середовища їх функціонування.

Ключові слова: сільськогосподарські підприємства, трансформація, інтеграція, механізм, моніторинг. 